\title{
Social networks and advertisement: legal issues
}

\section{Shokhjakhon KHUJAYEV 1}

Tashkent State University of Law

\begin{tabular}{l} 
ARTICLE INF0 \\
\hline Article history: \\
Received October 2021 \\
Received in revised form \\
15 October 2021 \\
Accepted 15 November 2021 \\
Available online \\
25 December 2021 \\
\\
\hline Keywords: \\
marketing, \\
special information, \\
copyright and related rights, \\
messenger, \\
Internet, \\
informatization.
\end{tabular}

\begin{abstract}
Currently, advertising on social networks is increasingly becoming the focus of consumer attention, arousing interest among marketers and businessmen. In this article, on the basis of the norms of the legislation of the Republic of Uzbekistan on advertising, informatization, intellectual property, tax legislation, the features of the legal regulation of advertising activities in social networks were analyzed. The legislation of the Republic of Uzbekistan does not provide for a separate regulatory legal act in the field of regulation of social networks, including advertising activities, in connection with which the author shows the "ways" of crossing the general requirements of legislation with the legal regulation of advertising in social networks. According to the results of the article, it is indicated that advertising activities in social networks can include two types of contracts - an agreement on the provision of services for the creation of advertising and an agreement on the provision of services for the placement of advertising, and it is also allowed to carry out activities based on the advertiser's public offer. In general, it is noted that effective legal regulation should be based on the simplicity of the legal mechanism, maximum simplification of the legal burden, as well as clear and fair taxation of subjects of advertising activities.
\end{abstract}

2181-1415/C 2021 in Science LLC.

DOI: https://doi.org/10.47689/2181-1415-vol2-iss11/S-pp118-124

This is an open access article under the Attribution 4.0 International (CC BY 4.0) license (https://creativecommons.org/licenses/by/4.0/deed.ru)

\section{Ижтимоий тармоқлар ва реклама: хуқуқий масалалар}

\author{
Калит сўзлар: \\ маркетинг, \\ махсус ахборот, \\ муаллифлик хуқуқи ва \\ турдош хуқуқлар, \\ мессенджер, \\ интернет, \\ ахборотлаштириш.
}

\section{АННОТАЦИЯ}

Хозирги кунда ижтимоий тармоқлардаги реклама тобора истеъмолчилар диққат марказига айланиб, маркетологлар ва ишбилармонлар орасида қизиқиш уйғотмоқда. Ушбу мақолада Ўзбекистон Республикасининг реклама, ахборотлаштириш, интеллектуал мулк, солиқ қонунчилиги нормалари асосида ижтимоий тармоқларда реклама фаолиятини хуқуқий тартибга солиш хусусиятлари тахлил қилинган.

\footnotetext{
${ }^{1} \mathrm{PhD}$ in Law, Head of Department at Tashkent State University of Law. Tashkent, Uzbekistan.

E-mail: intertoto50@gmail.com
} 


\begin{abstract}
Ӱзбекистон Республикаси қонунчилигида ижтимоий тармоқларни, шу жумладан, реклама фаолиятини тартибга солиш сохасида алохида норматив-хуқуқий хужжат назарда тутилмаган, шу муносабат билан муаллиф ижтимоий тармоқларда рекламани хуқуқий тартибга солиш масаласи билан қонунчиликнинг умумий талабларини кесиб ўтиш “йўлларини" кўрсатган. Мақола натижасида ижтимоий тармоқларда реклама фаолияти икки турдаги шартнома реклама яратиш бўйича хизматлар кўрсатиш тўғрисидаги битим ва реклама жойлаштириш бўйича хизматларни тақдим этиш тўғрисидаги битимни ўз ичига олиши мумкинлиги, шунингдек, реклама берувчининг оммавий таклифи асосида фаолиятни амалга оширишга рухсат берилиши назарда тутилган. Умуман олганда, самарали хукуқий тартибга солиш хуқуқий механизмнинг соддалигига, хукуқий юкни максимал даражада соддалаштиришга, шунингдек, реклама фаолияти субъектларини аниқ ва адолатли солиққа тортишга асосланиши лозимлиги таъкидланади.
\end{abstract}

\title{
Социальные сети и реклама: правовые вопросы
}

Ключевые слова:
маркетинг,
специальная информация,
авторское право и
смежные права,
мессенджер,
Интернет,
информатизация.

\begin{abstract}
АННОТАЦИЯ
В настоящее время реклама в социальных сетях все чаще оказываются в центре внимания потребителей, вызывая интерес среди маркетологов и бизнесменов. В данной статье на основе норм законодательства Республики Узбекистан о рекламе, информатизации, интеллектуальной собственности, налогового законодательства были проанализированы особенности правового регулирования рекламной деятельности в социальных сетях. Законодательство Республики Узбекистан не предусматривает отдельного нормативно-правового акта в сфере регулирования социальных сетей, включая рекламную деятельность, в связи с чем автор показывает «пути» пересечения общих требований законодательства с правовым регулированием рекламы в социальных сетях. По итогам статьи указывается, что рекламная деятельность в социальных сетях может включать два вида договора - договор об оказании услуг по созданию рекламы и договор об оказании услуг по размещению рекламы, а также допускается осуществление деятельности на основе публичной оферты рекламодателя. В целом отмечается, что эффективное правовое регулирование должно основываться на простоте правового механизма, максимальном упрощении юридического бремени, а также четком и справедливом налогообложении субъектов рекламной деятельности.
\end{abstract}

Сегодня социальные сети стали не только платформой для общения и диалога людей, но и создали отличную и удобную возможность для продвижения бизнеса. Не является и исключением реклама, которая создает множество возможностей для повышения уровня предпринимательства. Социальные сети, отличаются своей 
«лаконичностью» и удобством, в связи с чем осуществление рекламной деятельности в социальных сетях стало повседневной деятельностью и оптимизации расходов, как для крупных компаний, так и для малого и среднего бизнеса.

Несмотря на начальный спад из-за пандемии Covid-19, расходы на цифровую рекламу выросли именно в период пандемии. Крупнейшие игроки рекламного мира еще больше укрепили свои позиции, как раз на рынке цифровой рекламы из-за эффективности подобной деятельности в условиях пандемии.

Рынок рекламы в социальных сетях является вторым по величине рынком цифровой рекламы. Во всем мире социальные сети стали приносить все большие доходы. Так в 2021 году рынок рекламы в социальных сетях принес доход в размере 153,7 миллиарда долларов США. Ожидается, что мировой доход в текущем 2021 году вырастет до 252,6 миллиарда долларов США в 2026 году [8]. Расходы на рекламу в социальных сетях резко возросли во всем мире, но особенно в США. Согласно данным, представленным TradingPlatforms.com расходы на рекламу в социальных сетях в США, по прогнозам, впервые превысят отметку в 50 миллиардов долларов по итогам 2021 года [9]. Подобная статистика показывает важность рекламы, как атрибута бизнеса в социальных сетях, как альтернативы других видов рекламы. Однако экономический эффект, является стабильным лишь при соответствующем правовом обеспечении. Следовательно, правовое регулирование рекламной деятельности социальных сетей имеет особое значение.

Законодательство Республики Узбекистан не предусматривает отдельного нормативно-правового акта в сфере регулирования социальных сетей, включая рекламную деятельность. Однако существующие нормы действующего законодательства показывает «пути» пересечения общих требований законодательства с правовым регулированием рекламы в социальных сетях. Правовые вопросы включает следующие аспекты.

Bo-первых, реклама в социальных сетях осуществляется по общим правилам производства и распространения рекламы. Производство и распространение рекламы сопряжено с общими правилами. Так, реклама в Республике Узбекистан может распространяться на любом языке (статья 5 Закона Республики Узбекистан «0 рекламе»). Специфических ограничений в этом вопросе нет.

Требования к рекламе в социальных сетях включают четыре критерия:

законность- при распространении рекламы следует руководствоваться нормами действующего законодательства (например, нельзя рекламировать культ насилия или жестокость);

точность - реклама должна быть конкретной, отождествляться с определенным субъектом, товаром, работой или услугой (например, реклама ручки отождествляется с производителем ручек и самой ручкой);

достоверность - реклама не должна содержать ложные сведения или фальсификацию;

использование форм и средств, не причиняющих потребителю рекламы убытков, а также морального вреда.

Реклама в социальных сетях, как и любая реклама, должна быть отделена от иных сведений и информации. Распространяемая в социальных сетях реклама должна быть идентифицируема. Например, реклама в мессенджере Facebook должна содержать недвусмысленное обращение к рекламируемому субъекту, товару, работе, услуге и помещена под рубрикой «Реклама» либо «На правах рекламы». 
При производстве и размещении рекламы в социальных сетях следует соблюдать требования рекламы отдельных объектов (лекарственных средств, средств косметики и бытовой химии, энергетических напитков, табачных изделий и алкогольных напитков).

Bo-вторых, рекламная деятельность в социальных сетях осуществляется, как правило, согласно заключенному гражданско-правовому соглашению между заказчиком рекламы и изготовителем и (или) распространителем рекламы. Рекламная деятельность включает участие двух или трех субъектов рекламодателя, производителя рекламы или распространителя рекламы (последними два может быть одно лицо). Отношения между ними носят гражданско-правовой характер. С учетом специфики деятельности в социальных сетях, виртуального характера отношений [5] в них можно указать, что в рассматриваемом случае речь идет о возмездном оказании услуг. Рекламодатель выступает в качестве заказчика, а остальные субъекты - исполнителя. Предметом договора являются рекламные услуги. Кроме возмездного характера договора следует указать на его консенсуальный характер - согласование существенных условий достаточно для признания договора заключенным.

Рекламная деятельность в социальных сетях может включать два вида договора - договор об оказании услуг по созданию рекламы и договор об оказании услуг по размещению рекламы. Эти договора могут быть объединены в единый договор.

Заключение письменного договора не является обязательным. Рекламные услуги могут быть оказаны на основе акцепта публичной оферты рекламодателя. При отказе исполнения обязательств рекламодателем исполнитель может обратиться в суд с требованием понуждении рекламодателя заключить договор и компенсировать убытки.

$\boldsymbol{B}$-третьих, рекламная деятельность в социальных сетях может быть рассмотрена как часть процесса информатизации. Учитывая статус рекламы в качестве информации, к ней применяются правила об информатизации. Так, статья $12^{1}$ Закона Республики Узбекистан «Об информатизации» предусматривает правила распространения общедоступной информации во всемирной информационной сети Интернет, включая в социальных сетях. Так, размещающий в социальных сетях рекламу владелец страницы (группы или канала) в социальных сетях или блогер обязаны проверять достоверность общедоступной рекламы до ее размещения, не допускать размещения противоправного контента [1]. Как указывает А.Расулев, требования к информатизации имеют важное значение в целях обеспечения информационной безопасности в условиях коронавируса $[4,226$ c]. В целом нарушение прав третьих лиц в рекламе может стать причиной обращения в суд с иском о защите прав, чести, достоинства и деловой репутации, в том числе о возмещении убытков, компенсации морального вреда.

$\boldsymbol{B}$-четвертых, реклама в социальных сетях может являться объектом интеллектуальной собственности. Следует отметить, что статья 10 Закона Республики Узбекистан «О рекламе» указывает на возможность рассмотрения рекламы как объекта авторского права или смежных прав. В статье 6 Закона Республики Узбекистан «О рекламе» указывается на запрет нарушения прав авторов или правообладателей в рекламе. В частности, не допускается: 
имитировать (копировать или подражать) общее решение, текст, изображение, музыкальные или звуковые эффекты, применяемые в рекламе другой продукции;

рекламировать продукцию под видом рекламы другой продукции, товарный знак или знак обслуживания которой, тождествен или сходен до степени смешения с товарным знаком или знаком обслуживания продукции, реклама которой запрещена либо в отношении рекламы которой установлены соответствующие ограничения или требования.

Реклама может быть объектом авторского права (аудиовизуальное произведение), смежных прав (исполнения, танцы или игры), патентного права (промышленный образец), средством индивидуализации (обозначение и т.д.) в зависимости от представляемой информации. Однако рассмотрение самой рекламы в качестве объекта интеллектуальной собственности не приводится в тексте Закона Республики Узбекистан «О рекламе». Понятие рекламы дается через призму «специальной информации», что практически стирает грани между определенным материалов в виде информации (сведения о свойстве или качестве товаров) и рекламой. Цель рекламы - это предоставление информации в целях получения прибыли (дохода). Поэтому, следует согласиться с мнением Е.А. Свиридовой о том, что рекламу следует рассмотреть, как способ индивидуализации субъекта, товара, работы или услуги [6.C.88]. Так, например, реклама Coca Cola напрямую индивидуализирует данный напиток и обращает внимание потребителя на этот товар. Данная реклама позволяет выделить рекламируемый напиток от иных напитков подобного рода. Реклама направлена именно на «выделение» отдельного субъекта, товара, работы или услуги. В свою очередь, данное «выделение» является результатом творческой и умственной деятельности. Требования законодательства о рекламе приписывают запрет нарушения прав других авторов и правообладателей, это дает нам основание предполагать, что правомерная реклама обладает критериями творчества и оригинальности. Следовательно, метод подачи информации в рекламе позволяет отнести ее к объектам интеллектуальной собственности в виде средств индивидуализации. В связи с этим, целесообразно обсудить вопрос о рассмотрении рекламы в качестве средства индивидуализации. Это позволит конкретизировать статус рекламы в разрезе с интеллектуальной собственностью.

$\boldsymbol{B}$-пятых, законодатель в Узбекистане определяет физическое лицо субъекта, осуществляющего рекламную деятельность в социальных сетях, то есть изготовителя и распространителя рекламы в качестве самозанятого лица. Согласно нормам постановления Президента Республики Узбекистан от 9 июня 2020 года № ПП-4742 «0 мерах по упрощению государственного регулирования предпринимательской деятельности и самозанятости» деятельность в социальных сетях (имеется в виду такие профессии, как PR-менеджер, интернет-маркетолог, продвижение и реклама товаров (работ, услуг) в социальных сетях (SMM), администратор страниц в социальных сетях, аккаунт-менеджер, маркетолог, линкменеджер, таргетолог, специалист по контекстной рекламе, директолог, медиапланировщик, SMO-специалист), включая изготовителя и распространителя рекламы в социальных сетях входит в перечень видов деятельности (работ, услуг), которыми могут заниматься самозанятые лица. Статус самозанятости включает ряд льгот и преференций. Так, к самозанятым лицам применяются следующие льготы: 
- доходы, которые получены в результате рекламной деятельности самозанятых лиц в социальных сетях, не включаются в состав совокупного дохода физического лица согласно Налоговому кодексу Республики Узбекистан;

- для занятия рекламной деятельностью необходима регистрация в уведомительном порядке через специальное мобильное приложение либо персональный кабинет налогоплательщика с выдачей матричного штрихового кода (QR-код), удостоверяющего факт регистрации в качестве самозанятого;

- они уплачивают социальный налог в размере не менее одного размера базовой расчетной величины в год в добровольном порядке (статья 408 Налогового кодекс Республики Узбекистан);

- они могут принимать от нерезидентов из-за рубежа оплату в иностранной валюте за оказанные услуги на счета в банках Республики Узбекистан без внесения соответствующей информации в Единую электронную информационную систему внешнеторговых операций;

- они вправе оказывать услуги иностранным физическим и юридическим лицам без заключения контракта путем принятия публичного предложения о соглашении (оферты) или обмена электронными сообщениями либо выставлением счетов-фактур (инвойс), в том числе в электронном виде [2].

Если рекламная деятельность осуществляется субъектами предпринимательства, то применяются общие правила. Так производство и размещение рекламы относятся к видам деятельности, которыми могут заниматься индивидуальные предприниматели без образования юридического лица [3]. Юридические лица также вправе заниматься рекламным бизнесом. При этом Налоговый кодекс Республики Узбекистан определяет услуги рекламного характера в сети Интернет, включая в социальных сетях, как услуги в электронной форме.

Подводя итоги вышеизложенного, можно отметить, что монетизация социальных сетей и коммуникационных приложений все еще развивается, что делает ее потенциал роста на ближайшие годы очень позитивным. Несмотря на то, что база пользователей некоторых платформ приближается к максимальному уровню насыщения на некоторых рынках, улучшения в интеграции онлайнпокупок и платежных решений помогут обеспечить прибыльное будущее для социальных сетей. В связи с этим эффективное правовое регулирование должно основываться на простоте правового механизма, максимальном упрощении юридического бремени, а также четком и справедливом налогообложении субъектов рекламной деятельности.

\section{ФОЙДАЛАНИЛГАН АДАБИЁТЛАР РЎЙХАТИ:}

1. Закон Республики Узбекистан от 11 декабря 2003 года № 560-II «Об информатизации» (источник: https://www.lex.uz/docs/82956).

2. Постановление Президента Республики Узбекистан от 8 июня 2020 года № ПП4742 «0 мерах по упрощению государственного регулирования предпринимательской деятельности и самозанятости» (Источник: https://lex.uz/docs/ 4849605).

3. Постановление Кабинета Министров Республики Узбекистан от 7 января 2011 года № 6 «Об утверждении перечня видов деятельности, которыми могут заниматься индивидуальные предприниматели» (источник: https://lex.uz/docs/ 1727492). 
4. Расулев А. Информационная безопасность в условиях пандемии коронавируса // Review of law sciences. - 2020. - №. 2. - С. 224-228.

5. Рустамбеков И. Регулирование гражданско-правовых отношений в сети Интернет // Т.: ТГЮУ. - 2017.

6. Свиридова Е.А. Реклама как индивидуализирующее творческое представление. Диссертация на соискание ученой степени кандидата юридических наук. Москва, 2007. - С. 243.

7. Рахмонова М. Проблемы правоприменительной практики защиты прав на товарные знаки и возможные пути их разрешения // Review of law sciences. - 2020. - Т. 2. - №. Спецвыпуск. - С. 97-104.

8. https://www.statista.com/study/36294/digital-advertising-report-socialmedia-advertising/.

9. https://adobomagazine.com/insight/insight-social-media-advertising-revenuein-the-us-to-pass-50b-in-2021-85-from-mobile-ads/. 